\title{
Incorporation of $\mathrm{Ni}(\mathrm{II})$-dimethylglyoxime ion-imprinted polymer into electrospun polysulphone nanofibre for the determination of $\mathrm{Ni}(\mathrm{II})$ ions from aqueous samples
}

\author{
Modise Rammika ${ }^{1 *}$, Godfred Darko² and Nelson Torto ${ }^{2}$ \\ ${ }^{1}$ Department of Agricultural Research, Private Bag 0033, Gaborone, Botswana \\ ${ }^{2}$ Department of Chemistry, Rhodes University, PO Box 94, Grahamstown 6140, South Africa
}

\begin{abstract}
$\mathrm{Ni}(\mathrm{II})$-dimethylglyoxime ion-imprinted polymer (Ni(II)-DMG IIP) was encapsulated in polysulphone and electrospun into nanofibres with diameters ranging from 406 to $854 \mathrm{~nm}$. The structures of the Ni(II)-DMG encapsulated-IIP nanofibre, non-imprinted encapsulated-polymer nanofibre and polysulphone nanofibre mats were observed by scanning electron microscopy and evaluated by infrared spectroscopy. Electrospinning increased the specific surface area of the Ni(II)-DMG encapsulated-IIP nanofibre mats, as was evidenced by the low masses of the Ni(II)-DMG encapsulated-IIP nanofibre mats used. The accuracy of the method was validated by analysing a custom solution of certified reference material (SEP-3); the concentration of $\mathrm{Ni}(\mathrm{II})$ obtained was close to the certified one. The limit of detection was found to be $4.0 \times 10^{-4} \mu \mathrm{g} \cdot \mathrm{m} \ell^{-1}$ while the limit of quantification was found to be $1.2 \times 10^{-3} \mu \mathrm{g} \cdot \mathrm{m}^{-1}$. The recovery of $\mathrm{Ni}$ (II) achieved using the $\mathrm{Ni}$ (II)-DMG imprinted nanofibre mats in water samples was found to range from 83 to $89 \%$, while that of non-imprinted nanofibre mats was found to range from 59 to $65 \%$, and that of polysulphone from 55 to $62 \%$.
\end{abstract}

Keywords: electrospun encapsulated imprinted polymer nanofibres, aqueous samples, recovery

\section{Introduction}

Contamination of water by heavy metals is a major concern around the world (Momodu and Anyakora, 2010; Mansour and Sidky, 2002; Rico et al., 1989; Miller et al., 2004; Dhakate and Singh, 2008). Heavy metals are ranked high among the most important pollutants in natural and treated water resources. Though they occur only in trace concentrations $\left(\mathrm{mg} \cdot \ell^{-1}\right)$ in the environment, they tend to bioaccumulate in the food chain and exert various health effects on humans. There is therefore the need for a regular, quick and accurate determination of the heavy metals in the environment. The direct quantification of the heavy metals in samples has, however, proven to be a challenge as their concentrations are usually below the detection limits of many analytical instruments. It is therefore important to have more rigorous sample pre-treatment methods in order to remove complex matrices before analysis. Various pre-concentration techniques, such as open beaker acid digestion (Balcerzak, 2002; Rechcigl and Payne, 1989), microwave digestion (Rechcigl and Payne, 1989; Sarin et al., 2004), slurry techniques (Lima et al., 2000), chemical precipitation (Massoumi and Hedrick, 1969), electro-deposition (Ruotolo and Gubulin, 2002), cementation (Chang et al., 2007), ultra-filtration (Hong et al., 1998), ion exchange (Shao et al., 1991), activated carbon adsorption (Wilson et al., 2006), liquid-liquid extraction (Bhaskara and Reddy, 2002) and solid phase extraction (Hennion, 1999) (SPE), have been used to abstract trace metals from matrices. These methods have the limitation of poor selectivity, as one sorbent normally picks up several metal ions at once (Pourreza et al., 2010). SPE can be combined with ion-imprinted polymers (IIPs) in order to improve selectivity for ions (analytes) of interest from environmental

\footnotetext{
* To whom all correspondence should be addressed.

푤 +267714143 53; fax: +267 3928965 ; e-mail: modiserammika@yahoo.co.uk

Received 3 February 2011; accepted in revised form 5 September 2011 .
}

samples (Ramakrishnan and Rao, 2006; Otero et al., 2009; Romaní et al., 2009; Zhu et al., 2009; Krishna et al., 2004).

Ion-imprinted polymers (IIPs) are highly selective crosslinked polymeric materials, synthesised by complexing a template (metal ion) and a functional monomer in the presence of a crosslinker (Nishide et al., 1976). The reaction proceeds via a free radical initiator in an appropriate solvent normally referred to as a porogen. Removal of the template reveals cavities that are complementary in size and charge to the metal of interest. The memory is a result of the effect of the size and charge of the metal ion that was present in the cavity during polymerisation. Hence the cavities have a high recognition/selectivity for the metal ion only. The functional mechanism is similar to that of antibodies or enzymes. However, IIPs have advantages over antibodies in that they are cheap to produce and can be used in or with a variety of solvents at high temperature, pressure and $\mathrm{pH}$ conditions which antibodies or enzymes would not tolerate.

However, the imprinted polymers also have limitations; for example, the highly cross-linked polymer makes it difficult to completely remove the template (template bleeding) (Ki et al., 2002; Rao and Dave, 1998). There is also a challenge of slow rebinding due to the fact that most of the imprinted sites are not always on the surface (Carter and Rimmer, 2002; 2004). Therefore it is essential to introduce nanotechnology and surface chemistry into imprinted polymers (Xie et al., 2006; 2008). Nanomaterials are becoming popular in sample preparation techniques because of their small size, which enables them to be used in preference to bulk materials (Yoshimatsu et al., 2008a; Chronakis et al., 2006a, 2006b; Flavin and Resmini, 2009; Duan et al., 2008; Lehmann et al., 2002). There are several methods that can be used to introduce the IIPs into nanomaterials. These include nanomoulding, which is used to produce imprinted nanowires (Yang et al., 2005), preparation of surface-imprinted nanowires, which is used to produce imprinted nanotubes (Xie et al., 2006), and electrospinning, which is used to incorporate imprinted nanoparticles into 
electrospun nanofibres (Wang et al., 2006; Chronakris et al., 2006a; Yoshimatsu et al., 2008a, 2008b). Electrospinning is the most efficient, simple, and versatile method of introducing nanomaterials into sample preparation techniques, due to its relatively simple and cost-effective setup (Miao et al., 2010; Wang et al., 2009; Teo and Ramakrishna, 2005; 2009; Subbiah et al., 2005; Zhang et al., 2005).

Electrospinning is a process for producing continuous polymer nanofibres, of diameter 10-1 $000 \mathrm{~nm}$, through the application of a high voltage to the polymer solution (Ramakrishna et al., 2005; Wang et al., 2009; Miao et al., 2010; Duan et al., 2008; Jantarat et al., 2008; Teo and Ramakrishna, 2009; Lehmann et al., 2002; Kriegel et al., 2008). The process takes place at an optimal voltage, when the charge induced on the polymer solution is sufficient to overcome the surface tension. A jet is formed and ejected towards a grounded collector, which is normally aluminium foil (Ramakrishna et al., 2005; Wang et al., 2009; Miao et al., 2010; Kriegel et al., 2008). Due to their small size, the nanofibres have high specific surface areas, which enhances the interaction between analyte and sorbent, thus improving adsorption performance.

This paper reports the synthesis of nickel (II)-dimethyl glyoxime encapsulated ion-imprinted polymer (Ni(II)-DMG IIP) nanofibre mats that were used to selectively trap $\mathrm{Ni}$ (II) ions in aqueous solutions. This is the first encapsulated-polymer nanofibre work performed with ion-imprinted polymers synthesised by bulk polymerisation. The polymerisation methods used by previous studies were precipitation polymerisation (Yoshimatsu et al., 2008a; Chronakis et al., 2006a) and miniemulsion polymerisation (Lehmann et al., 2002).

\section{Experimental}

\section{Chemicals and reagents}

Analytical grade ammonium acetate, 4-vinylpyridine, 2,2'azobisisobutyronitrile (AIBN), 2-methoxy ethanol, styrene, nickel(II) sulphate hexahyrate $\left(\mathrm{NiSO}_{4} \cdot 6 \mathrm{H}_{2} \mathrm{O}\right)$, divinyl benzene, dimethylglyoxime (DMG), trace metal grade nitric acid, hydrochloric acid, dimethyl formamide, polysulphone and stock solution of $\mathrm{Ni}$ (II) were obtained from Sigma Aldrich (Steinheim, Germany). Filter paper was acquired from Whatman (Maidstone, UK). An A10 milli-Q system from Millipore RiOs (Bedford, USA) was used to generate ultrapure water. A custom solution of certified reference material (CRM), SEP-3, was obtained from Inorganic Ventures (Christiansburg, USA).

\section{Instrumentation}

Scanning electron microscopy images were acquired by a TS5136ML Digital Vega Microscope from Tescan (Brno, Czech Republic). FTIR (400-4 $000 \mathrm{~cm}^{-1}$ ) spectra were recorded on a PerkinElmer Spectrum 100 spectrometer (Massachusetts, USA) equipped with a universal ATR sampling accessory. Concentrations of metals were determined using an iCAP 6000 Series inductively coupled plasma-optical emission spectrometer (ICP-OES) from Thermo Electron Corporation (Cheshire, United Kingdom). The solution $\mathrm{pH}$ was measured using the Jenway 3510 pH meter (Essex, UK).

\section{Preparation of the Ni(II)-DMG IIP}

$\mathrm{Ni}(\mathrm{II})-\mathrm{DMG}$ IIP and non ion-imprinted polymers were prepared using the protocol described by Rammika et al. (2011).
The optimisation was carried out by the uniform design experimental method (Rammika et al., unpublished data; Zhu et al., 2007). It was ensured that only the finest particles passed through the $2 \mu \mathrm{m}$ sieve.

\section{Preparation of Ni(II)-DMG IIP suspension solution}

$200 \mathrm{mg}$ of Ni(II)-DMG IIP was suspended in $10 \mathrm{~m} \ell$ dimethyl formamide and $200 \mathrm{mg}$ polysulphone (PSU) and the solution was stirred for $3 \mathrm{~h}$.

\section{Electrospinning}

The electrospinning of the Ni(II)-DMG IIP suspended in dimethyl formamide and polysulphone, to form Ni(II)-DMG nanofibre mats, was carried out at room temperature at a positive voltage of $15 \mathrm{kV}$; a counter electrode was set at $5 \mathrm{kV}$. A copper wire was mounted on the spinneret and used as a positive electrode. Aluminium foil was used a counter electrode and mounted at a distance of $12 \mathrm{~cm}$ from the spinneret. Fibres were collected on the aluminium foil in the form of a mat. The mat was stored in a desiccator for $6 \mathrm{~h}$ to remove solvent and the fibre was then washed 3 times with $50 \% \mathrm{HCl}$ and 3 times with ultrapure water. $30 \mathrm{~m} \ell$ of aqueous sample was spiked with $2 \mu \mathrm{g} \cdot \mathrm{m} \ell^{-1}$ of $\mathrm{Ni}(\mathrm{II})$ and $15 \mathrm{mg}$ of $\mathrm{Ni}(\mathrm{II})$-DMG encapsulated-IIP nanofibre mats or non-imprinted nanofibre mats was put into the sample. The sample was shaken for $1 \mathrm{~min}$ and the change in $\mathrm{Ni}$ (II) concentration was taken to be the concentration of $\mathrm{Ni}$ (II) adsorbed by the nanofibre mats.

\section{Sample collection and preparation}

Sea, river, untreated sewage and treated sewage water samples were collected in polyethylene containers by the grab sampling method. $100.0 \mathrm{~m} \ell$ portions of water samples doused with $2.0 \mathrm{~m} \ell$ conc. $\mathrm{HNO}_{3}$ and $5.0 \mathrm{~m} \ell$ conc. $\mathrm{HCl}$ were digested by heating on a hot plate at $90^{\circ} \mathrm{C}$ until the volume was reduced to $20.0 \mathrm{~m} \ell$. The solution was then filtered through Whatman No. 1 filter paper after allowing it to cool, and diluted to $100.0 \mathrm{~m} \ell$ with ultrapure water prior to ICP-OES analysis (Method 3005A, 1992).

\section{Optimisation of $\mathrm{pH}$, mass and time}

A set of 3 replicates of $30.0 \mathrm{~m} \ell$ portions of $2 \mu \mathrm{g} \cdot \mathrm{m} \ell^{-1} \mathrm{Ni}$ (II) solutions were prepared and their $\mathrm{pH}$ adjusted from 1.0 to 12.0. From $\mathrm{pH}$ 1-3, the hydrochloric acid/ potassium chloride buffer was used, for $\mathrm{pH} 4-6$, sodium acetate buffer was used and for pH 7-12, the disodium hydrogen phosphate buffer was used. Then $10.0 \mathrm{mg}$ of Ni(II)-DMG encapsulated-IIP nanofibre mats was added into each solution and the solution was stirred for $5 \mathrm{~min}$. For mass optimisation, 5.0 to $60.0 \mathrm{mg}$ of leached Ni(II)DMG nanofibre mats were weighed into each solution and the solutions were shaken for $30 \mathrm{~min}$. To optimise for time needed for $\mathrm{Ni}(\mathrm{II})$ rebinding, equal volumes of $\mathrm{Ni}$ solutions $(30.0 \mathrm{m \ell})$ were taken and adjusted to $\mathrm{pH} 8.0$ using the disodium hydrogen phosphate buffer. Times for rebinding of $\mathrm{Ni}(\mathrm{II})$ ranging from $30 \mathrm{~s}$ to $300 \mathrm{~s}$ were evaluated.

In all of the experiments, the amount of $\mathrm{Ni}(\mathrm{II})$ adsorbed by $\mathrm{Ni}(\mathrm{II})-\mathrm{DMG}$ nanofibre mats was desorbed with $50 \% \mathrm{HCl}$ and the concentration of $\mathrm{Ni}(\mathrm{II})$ quantified by ICP-OES. This value was always not significantly different from the one obtained by taking the reduction in concentration of the $\mathrm{Ni}(\mathrm{II})$ solution as the amount trapped by the Ni(II)-DMG encapsulated-IIP 
nanofibre mats. The percentage extraction efficiency $(\% \mathrm{EE})$ was then calculated as shown in Eq. (1):

$$
\% \mathrm{EE}=\left(\frac{C i-C s}{C i}\right) \times 100
$$

where:

$C_{i}$ is the initial solution concentration $\left(\mu \mathrm{g} \cdot \mathrm{m} \ell^{-1}\right)$ and

$C_{s}$ is the solution concentration after adsorption.

Enrichment factors (EFs) s were calculated as shown in Eq. (2):

$$
\mathrm{EF}=\frac{b}{a}
$$

where:

$a$ is the $\mathrm{Ni}(\mathrm{II})$ conc. value obtained when using $\mathrm{Ni}(\mathrm{II})$ DMG nanofibre $\left(\mu \mathrm{g} \cdot \mathrm{m} \ell^{-1}\right)$ and

$b$ is the $\mathrm{Ni}$ (II) conc. value obtained without digestion $\left(\mu \mathrm{g} \cdot \mathrm{m} \ell^{-1}\right)$.

\section{Results and discussion}

\section{Characterisation of the morphology of the electrospun nanofibres}

The diameter of the Ni(II)-DMG encapsulated-IIP nanofibre mats (Figs. 1 and 2) ranged from 406 to $854 \mathrm{~nm}$ while that of polysulphone (Figs. 3 and 4) ranged from 571 to $1236 \mathrm{~nm}$ and that of DMG non-imprinted nanofibre mats (Fig. 5) from 574 to $823 \mathrm{~nm}$. The values for the nanofibre mats are in the nano range (1-1 $000 \mathrm{~nm})$, though DMG non-imprinted nanofibre mats were larger than the imprinted mats. As shown in Figs. 1 and 2, the Ni(II)-DMG encapsulated-IIP nanofibre and DMG nonimprinted nanofibre mats are rough, with some beads (which are presumably due to Ni(II)-DMG IIP and non-imprinted polymers), while PSU alone is smooth. In previous studies, diameters of 200-300 nm (Chronakis et al., 2006a; Chronakis et al., 2006b), 130-2 $400 \mathrm{~nm}$ (Yoshimatsu et al., 2008a) were obtained and non-imprinted nanofibre mats were found to be larger than the imprinted nanofibre mats, as was the case here (Figs. 1, 2 and 5).

\section{Infrared studies}

The IR spectrum of the Ni(II)-DMG encapsulated-IIP nanofibre mats (as shown in Fig. 6C) shows the presence of an $\mathrm{OH}$ deformation band at $1737 \mathrm{~cm}^{-1}$, indicating the formation of a hydrogen bridge (Burger et al., 1965; Cardoso et al., 2009; Nyquist, 2001). This hydrogen bridge confirms the formation of the red square planar Ni(II)-DMG IIP complex in the nanofibre mats and is absent in the PSU and in the DMG non-imprinted nanofibre mats (as shown in Figs. 6A and 6B). This $\mathrm{OH}$ deformation band was also present in Ni(II)-DMG IIP and absent for the DMG non-imprinted polymer (Rammika et al., 2011). There is a peak at $930 \mathrm{~cm}^{-1}$ in the spectra of both the DMG imprinted and non-imprinted nanofibre mats, which is due to the oxime functional group; this peak is absent from the spectra for polysulphone as this does not have an oxime group (Socrates, 2001).

\section{Optimisation of $\mathrm{pH}$, mass and time}

In $\mathrm{pH}$ adjustment studies, the $\mathrm{Ni}$ (II)-DMG encapsulated-IIP nanofibre mats were subjected to the extremes of $\mathrm{pH}$ which it was able to withstand. At $\mathrm{pH} 0$ to 4.0 the recoveries for the $\mathrm{Ni}(\mathrm{II})-\mathrm{DMG}$ encapsulated-IIP nanofibre mats ranged from
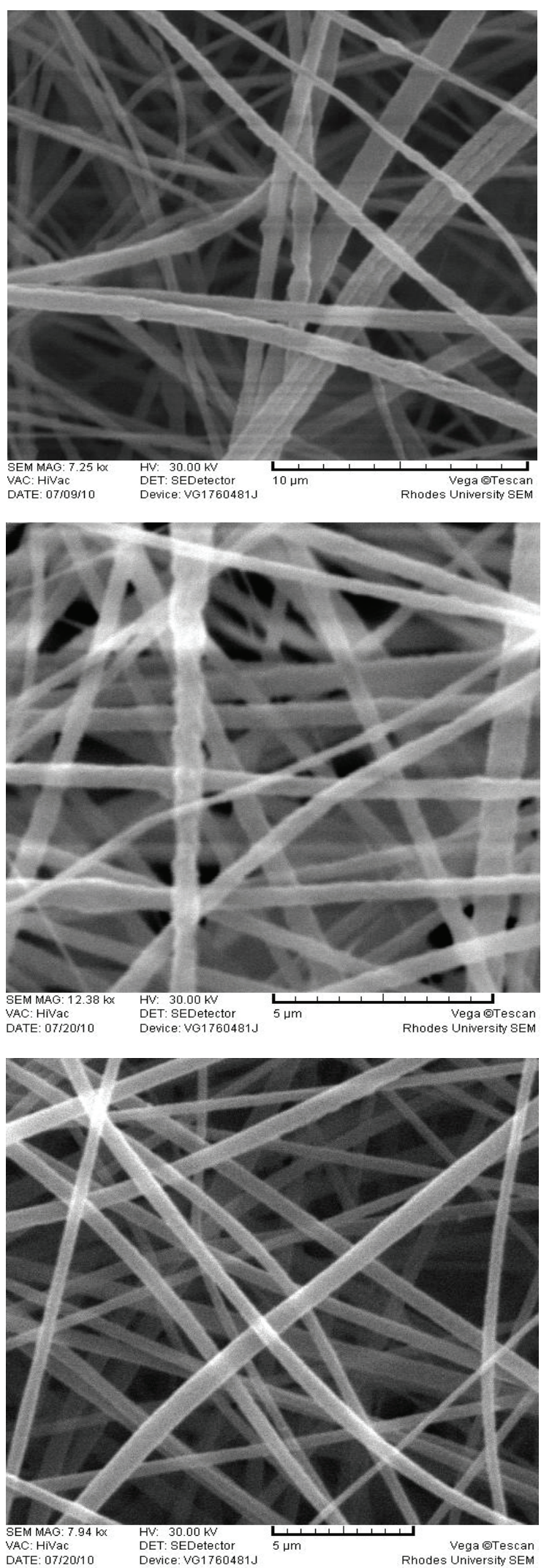

Figure 1 (top right)

SEM image for Ni(II)-DMG encapsulated-IIP nanofibre mats

Figure 2 (middle right)

SEM image for Ni(II)-DMG encapsulated-IIP nanofibre mats

Figure 3 (bottom right)

SEM image for polysulphone 


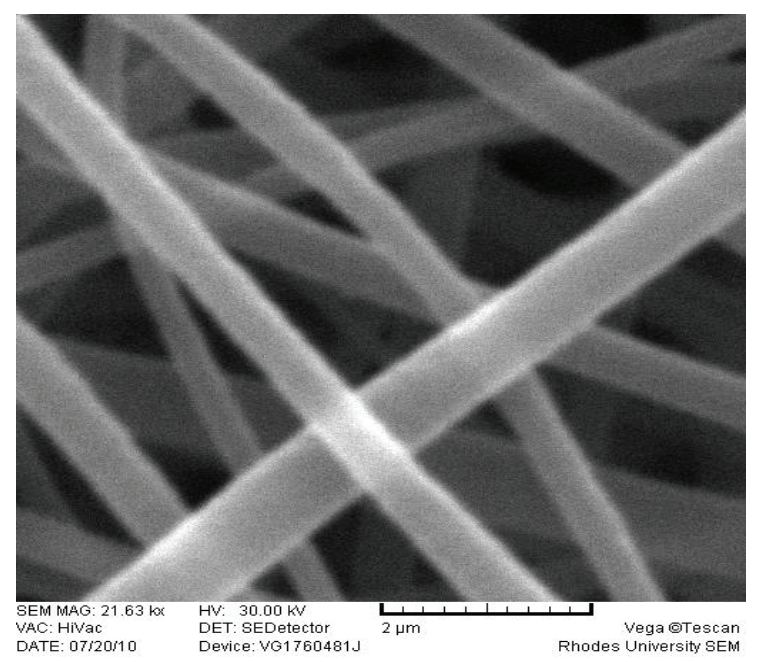

Figure 4

SEM image for polysulphone

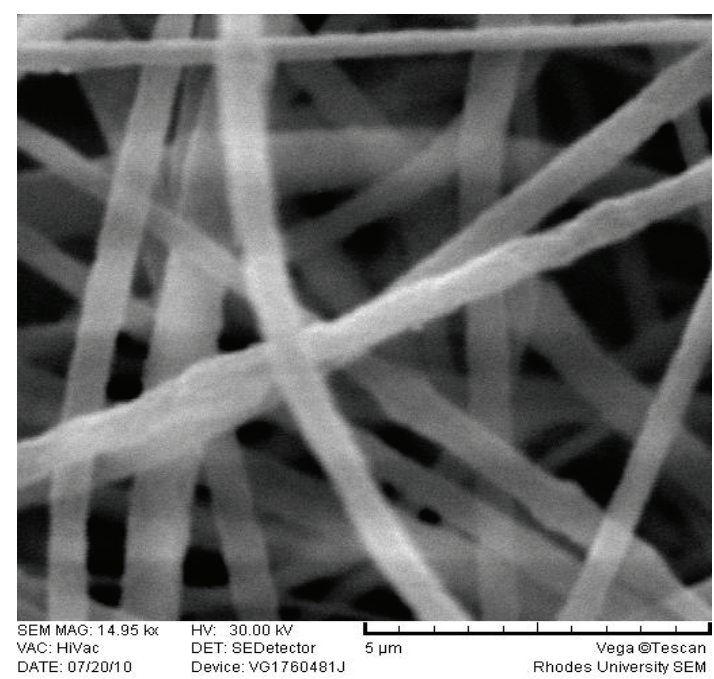

Figure 5

SEM image for non-imprinted nanofibre mats

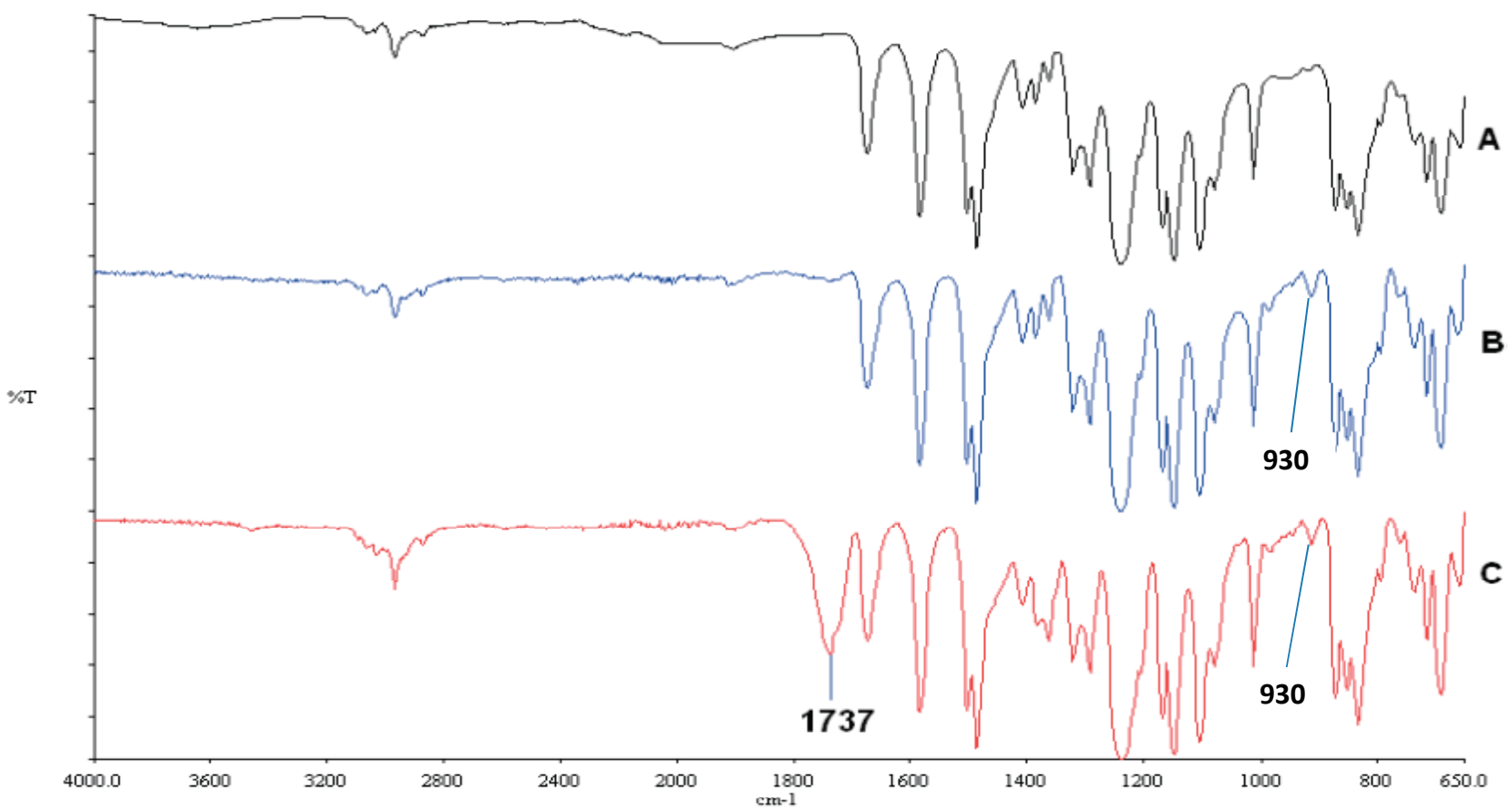

Figure 6

IR spectra of PSU (A), DMG non-imprinted (B) and Ni(II)-DMG encapsulated-IIP nanofibre mats (C)

0 to $26 \%$ and good recoveries $(72-84 \%)$ were recorded in the $\mathrm{pH}$ range of 6.0 to 10.0. Beyond $\mathrm{pH} 10.0$, recoveries dropped (Fig. 7). $15 \mathrm{mg}$ was taken as the optimum mass as recoveries increased from 59 to $84 \%$ as the mass was increased from 5 to $10 \mathrm{mg}$, but remained almost constant from 15 to $60 \mathrm{mg}$ (Fig. 8). The highest recovery obtained with this mass was $90 \%$, which is comparable to a recovery of $99.1 \%$ obtained by Amais et al. (2007), who used $50 \mathrm{mg}$ of multi-wall carbon nanotubes (which are also nanomaterials) as sorbent for on-line nickel pre-concentration in water samples. $50 \mathrm{mg}$ was also used for Ni(II)-DMG IIP (Rammika et al., 2011). Yoshimatsu et al. (2008a), using propranolol electrospun molecularly-imprinted nanoparticles, obtained a recovery of $80 \%$ in water samples, using a mass of $5 \mathrm{mg}$ of the nanofibre mat. Chronakris et al. (2006a) used $2 \mathrm{mg}$ of the fibre mat and achieved a recovery of $88 \%$ using poly(ethylene terephthalate) (PET) as the supporting nanofibre matrix to encapsulate theophylline and $17 \beta$-estradiol imprinted nanoparticles. $3.5 \mathrm{mg}$ of the nanofibre mat was used by Chronakris et al. (2006b), who obtained a recovery of $75 \%$ when they electrospun PET and polyallylamine in the presence of a template molecule, 2,4-dichlorophenoxyacetic acid (2,4-D), used the nanofibre to enrich 2,4-D from aqueous solutions. The optimum time required for binding of the $\mathrm{Ni}$ (II) to $\mathrm{Ni}$ (II)-DMG encapsulated-IIP nanofibre mats was $210 \mathrm{~s}$, as recoveries increased from $45 \%$ at $30 \mathrm{~s}$ to $90 \%$ at $210 \mathrm{~s}$, after which the recovery remained almost constant (Fig. 9). Though this was longer than the $60 \mathrm{~s}$ which was found to be optimal when using Ni(II)-DMG IIP (Rammika et al., 2011), it is less than the periods of $1 \mathrm{~h}$ (Yoshimatsu et al., 2008a) and 


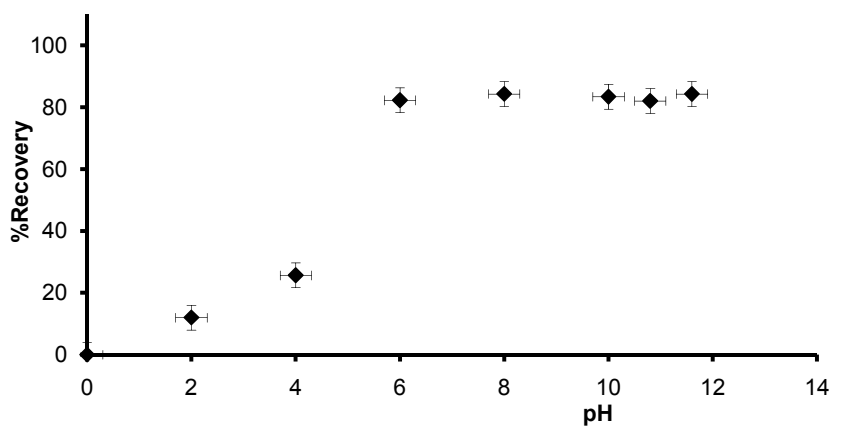

Figure 7

Effect of $\mathrm{pH}$ on recovery of Ni(II) for Ni(II) DMG nanofibre

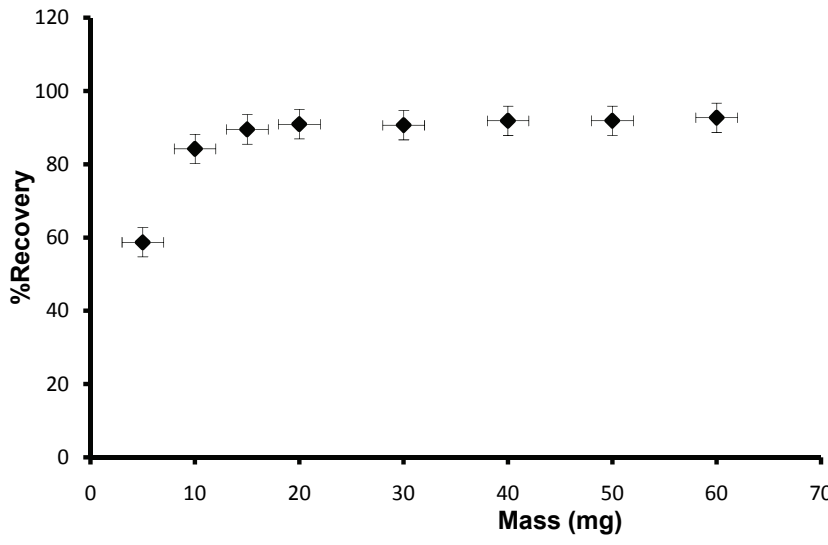

Figure 8

Effect of mass on recovery of $\mathrm{Ni}(\mathrm{II})$ for $\mathrm{Ni}(\mathrm{II}) \mathrm{DMG}$ nanofibre

$4 \mathrm{~h}$ (Chronakris et al., 2006a; Chronakris et al., 2006b) obtained previously with other imprinted nanofibres. The Ni(II)-DMG encapsulated-IIP nanofibre mats could be used up to 10 times without a noticeable decrease in recovery (Fig. 10). This is much better than the 2 times that was achieved with Ni(II)-DMG IIP (Rammika et al., 2011).

\section{Selectivity and interference studies}

The Ni(II)-DMG encapsulated-IIP nanofibre mats had high selectivity towards $\mathrm{Ni}(\mathrm{II})$, as the recovery for $\mathrm{Ni}(\mathrm{II})$ was much higher than for $\mathrm{Co}(\mathrm{II}), \mathrm{Cu}(\mathrm{II}), \mathrm{Zn}(\mathrm{II}), \mathrm{Pd}(\mathrm{II}), \mathrm{Ca}(\mathrm{II}), \mathrm{Mg}$ (II), $\mathrm{Na}(\mathrm{I})$ and $\mathrm{K}(\mathrm{I})$, demonstrating that the cavities in the $\mathrm{Ni}(\mathrm{II})$ DMG encapsulated-IIP nanofibre mats had higher affinity for $\mathrm{Ni}(\mathrm{II})$, as shown in Table 1. Despite the fact that Fe(II), Co(II) and $\mathrm{Cu}$ (II) (Zen and Lee, 1993; Ershova and Ivanov, 2000; De Sousa and Korn, 2001) are known to interfere with the complexation of nickel with DMG, these metals did not show any interference with the extraction efficiency of $\mathrm{Ni}(\mathrm{II})$ when the Ni(II)-DMG encapsulated-IIP nanofibre mats were used. Although DMG is selective to both $\mathrm{Pd}(\mathrm{II})$ and $\mathrm{Ni}(\mathrm{II})$, it seems that, in this case, $\mathrm{Ni}(\mathrm{II})$-specific cavities were created. This

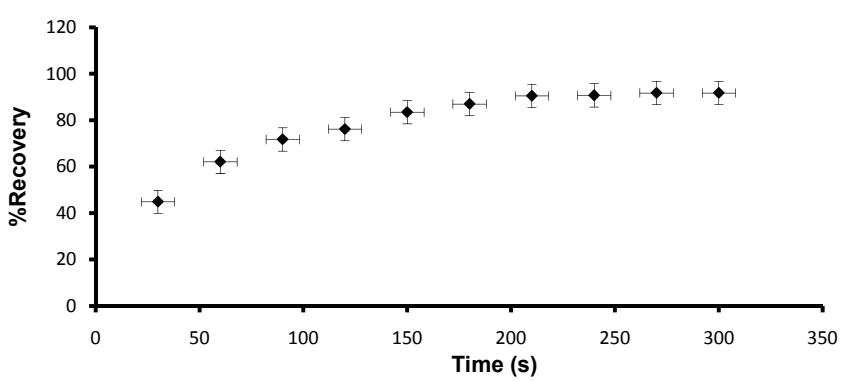

Figure 9

Effect of pre-concentration time on recovery of $\mathrm{Ni}(\mathrm{II})$ for $\mathrm{Ni}(\mathrm{II})$ DMG nanofibre

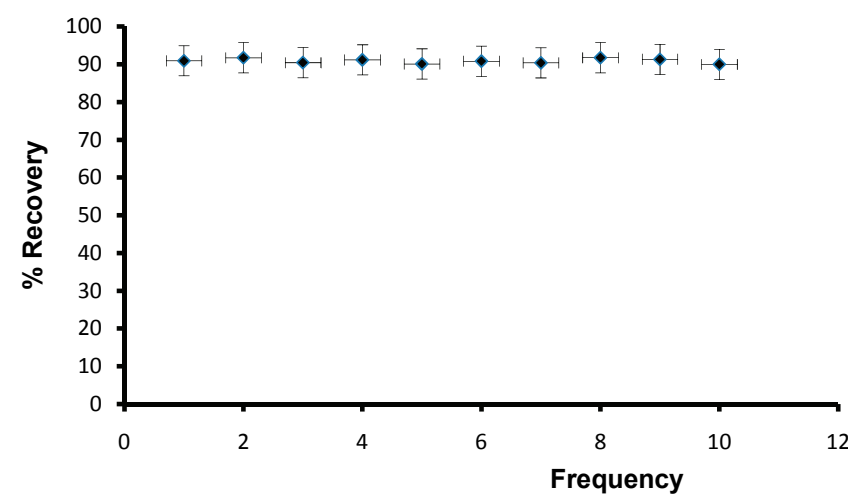

Figure 10

Effect of repeated use of Ni(II)-DMG encapsulated-IIP nanofibre mats on recovery of $\mathrm{Ni}(\mathrm{II})$

was evidenced by the lower extraction efficiencies recorded for $\mathrm{Co}(\mathrm{II}), \mathrm{Cu}(\mathrm{II}), \mathrm{Zn}(\mathrm{II})$ and $\mathrm{Pd}(\mathrm{II})$, which all have about the same size and charge as $\mathrm{Ni}(\mathrm{II})$. $\mathrm{Fe}(\mathrm{II})$ had a reasonably high recovery but did not interfere with the determination of $\mathrm{Ni}(\mathrm{II})$, as shown by the good recoveries of $\mathrm{Ni}(\mathrm{II})$ when $\mathrm{Fe}$ (II) concentration was increased from $2 \mu \mathrm{g} \cdot \mathrm{m} \ell^{-1}$ to $4 \mu \mathrm{g} \cdot \mathrm{m} \ell^{-1}$.

$\mathrm{Zn}(\mathrm{II}), \mathrm{Pd}(\mathrm{II}), \mathrm{Fe}(\mathrm{II}), \mathrm{Ca}(\mathrm{II}), \mathrm{Mg}(\mathrm{II}), \mathrm{Na}(\mathrm{I})$ and $\mathrm{K}(\mathrm{I}) \mathrm{did}$ not interfere with the binding of $\mathrm{Ni}(\mathrm{II})$ on the IIP, as shown in Table 2. $\mathrm{Cu}(\mathrm{II})$ and $\mathrm{Co}(\mathrm{II})$ were found to slightly interfere with the rebinding of $\mathrm{Ni}(\mathrm{II})$ and interaction studies were therefore performed for them, as shown by the last 4 entries in Table 2 . To compute the main effect of $\mathrm{Cu}$ (II) on $\mathrm{Ni}$ (II) for the 2-factorial design experiments, the average response at all runs with $\mathrm{Cu}(\mathrm{II})$ at the high setting were computed and the average response of all runs with $\mathrm{Cu}$ (II) set at low were subtracted (Montgomery, 2005). The same was done for the main effect of $\mathrm{Co}(\mathrm{II})$. Interaction between $\mathrm{Co}(\mathrm{II})$ and $\mathrm{Cu}(\mathrm{II})$ was calculated by multiplying the settings of $\mathrm{Co}(\mathrm{II})$ and $\mathrm{Cu}(\mathrm{II})$ and then averaging the responses at high setting and subtracting the average at low setting (Montgomery, 2005). The value of the effect of $\mathrm{Co}$ (II) on $\mathrm{Ni}(\mathrm{II})$ was found to be -4.5 while the effect of $\mathrm{Cu}(\mathrm{II})$ on $\mathrm{Ni}(\mathrm{II})$ was found to be -0.5 . For an interaction to

Table 1

The extraction efficiency (\%) of $\mathrm{Ni}(\mathrm{II})$-DMG nanofibre mats and non-imprinted DMG nanofibre mats $(n=3)$

\begin{tabular}{|l|c|c|c|c|c|c|c|c|c|c|}
\hline Metal ions & $\mathbf{N i}(\mathbf{I I})$ & $\mathbf{F e}(\mathbf{I I})$ & $\mathbf{C o}(\mathbf{I I})$ & $\mathbf{P d}(\mathbf{I I})$ & $\mathbf{C u}(\mathbf{I I})$ & $\mathbf{Z n}(\mathbf{I I})$ & $\mathbf{C a}(\mathbf{I I})$ & $\mathbf{M g}(\mathbf{I I})$ & $\mathbf{N a}(\mathbf{I})$ & $\mathbf{K}(\mathbf{I})$ \\
\hline $\begin{array}{l}\text { Ni(II)-DMG nanofibre } \\
\text { mats }\end{array}$ & 91 & 97 & 60 & 29 & 47 & 43 & 43 & 45 & 51 & 48 \\
\hline $\begin{array}{l}\text { Non-imprinted DMG } \\
\text { nanofibre mats }\end{array}$ & 66 & 96 & 41 & 24 & 42 & 41 & 51 & 52 & 48 & 52 \\
\hline
\end{tabular}


be taken as significant, it has to be more than 5 . This shows that the interference of the 2 metals in the recovery of $\mathrm{Ni}(\mathrm{II})$ is not significant. Most ion-imprinting and nanofibre literature does not present these data, which can help to evaluate the effect of $\mathrm{Co}(\mathrm{II})$ on rebinding of $\mathrm{Ni}(\mathrm{II})$, as the 2 ions compete severely (Griffing et al., 1947; Yang and Black, 1994; Kumbasar and Sahin, 2008). Interference studies by Amais et al. (2007) also showed that $\mathrm{Zn}(\mathrm{II}), \mathrm{Cd}(\mathrm{II}), \mathrm{Cu}(\mathrm{II}), \mathrm{Ba}(\mathrm{II}), \mathrm{Cu}(\mathrm{II}), \mathrm{Pb}$ (II), $\mathrm{Mn}(\mathrm{II}), \mathrm{Co}(\mathrm{II}), \mathrm{Cr}(\mathrm{III}), \mathrm{Ca}(\mathrm{II}), \mathrm{Mg}(\mathrm{II}), \mathrm{Na}(\mathrm{I})$ and $\mathrm{K}(\mathrm{I})$ did not interfere with the binding of $\mathrm{Ni}(\mathrm{II})$ on the multi-wall carbon nanotubes. Selectivity studies conducted by Yoshimatsu et al. (2008a) using propranolol electrospun molecularly-imprinted nanoparticles as a template showed that recoveries of up to $80 \%$ were achieved with propranolol analyte, whereas structural analogues of propranolol had recoveries of $30-50 \%$, which is still larger than the $15 \%$ recovery achieved with non-imprinted nanofibres. The propranolol-imprinted nanofibre mats were used to enrich propranolol from water samples.

\section{Analysis of CRM}

The developed method was validated by analysing a custom solution of CRM of water (SEP-3). The results (Tables 3 and 4) showed that the value obtained from the method is within

\begin{tabular}{|c|c|c|c|}
\hline \multicolumn{4}{|c|}{$\begin{array}{c}\text { Table } 2 \\
\mathrm{Ni}(\mathrm{II}) \text { recoveries for } \mathrm{Ni}(\mathrm{II}) \text {-DMG nanofibre mats after } \\
\text { addition of different levels of cations }(n=3)\end{array}$} \\
\hline $\begin{array}{l}\text { Element(s) } \\
\text { added }\end{array}$ & $\begin{array}{l}\text { Concentrations } \\
\text { of elements } \\
\text { added }\left(\mu \mathrm{g} \cdot \mathrm{m} \ell^{-1}\right)\end{array}$ & $\begin{array}{l}\text { Concentration } \\
\text { of } \mathrm{Ni}(\mathrm{II}) \\
\left(\mu \mathrm{g} \cdot \mathrm{m} \ell^{-1}\right)\end{array}$ & \% Recovery \\
\hline $\mathrm{Na}(\mathrm{I})$ & $2 ; 4$ & 2 & $89 ; 90$ \\
\hline $\mathrm{K}(\mathrm{I})$ & $2 ; 4$ & 2 & $90 ; 89$ \\
\hline $\mathrm{Ca}(\mathrm{II})$ & $2 ; 4$ & 2 & $85 ; 89$ \\
\hline $\operatorname{Mg}(\mathrm{II})$ & $2 ; 4$ & 2 & $87 ; 88$ \\
\hline $\begin{array}{l}\mathrm{Ca}(\mathrm{II}), \mathrm{Mg}(\mathrm{II}), \\
\mathrm{Na}(\mathrm{I}) \text { and } \mathrm{K}(\mathrm{I})\end{array}$ & $2 ; 4$ & 2 & $89 ; 83$ \\
\hline $\mathrm{Co}(\mathrm{II})$ & $2 ; 4$ & 2 & $84 ; 77$ \\
\hline $\operatorname{Pd}(\mathrm{II})$ & $2 ; 4$ & 2 & $85 ; 82$ \\
\hline $\mathrm{Cu}(\mathrm{II})$ & $2 ; 4$ & 2 & $87 ; 81$ \\
\hline $\mathrm{Zn}(\mathrm{II})$ & $2 ; 4$ & 2 & $87 ; 83$ \\
\hline $\mathrm{Fe}(\mathrm{II})$ & $2 ; 4$ & 2 & $89 ; 86$ \\
\hline All above & $2 ; 4$ & 2 & $76 ; 67$ \\
\hline $\mathrm{Co}(\mathrm{II}) ; \mathrm{Cu}(\mathrm{II})$ & $2 ; 2$ & 2 & 86 \\
\hline $\mathrm{Co}(\mathrm{II}) ; \mathrm{Cu}(\mathrm{II})$ & $2 ; 4$ & 2 & 87 \\
\hline $\mathrm{Co}(\mathrm{II}) ; \mathrm{Cu}(\mathrm{II})$ & $4 ; 2$ & 2 & 83 \\
\hline $\mathrm{Co}(\mathrm{II}) ; \mathrm{Cu}(\mathrm{II})$ & $4 ; 4$ & 2 & 81 \\
\hline
\end{tabular}

the error of the CRM value. The \%RSD was found to be 4.57 . Accuracy of the determinations, expressed as relative error between the certified and the observed values of the reference material, were $\leq 0.3 \%$. The precision of these measurements, expressed as RSD for 5 independent determinations, was also satisfactory, being lower than $5 \%$ in all cases. The limit of detection (LOD) of Ni(II) using the Ni(II)-DMG encapsulated-IIP nanofibre mats was found to be $0.0004 \pm 0.0001 \mu \mathrm{g} \cdot \mathrm{m} \ell^{-1}$ while the limit of quantification (LOQ) was $0.0012 \mu \mathrm{g} \cdot \mathrm{m} \ell^{-1}$, whereas the LOD and LOQ of Ni(II)-DMG IIP (Rammika et al., 2011) was found to be $0.0003 \pm 0.0001 \mu \mathrm{g} \cdot \mathrm{m} \ell^{-1}$ and $0.0009 \mu \mathrm{g} \cdot \mathrm{m} \ell^{-1}$, respectively. Amais et al. (2007) used multi-wall carbon nanotubes as sorbent for on-line nickel preconcentration in water samples and obtained an LOD of $0.0041 \mu \mathrm{g} \cdot \mathrm{m}^{-1}$ and an LOQ of $0.0136 \mu \mathrm{g} \cdot \mathrm{m} \ell^{-1}$. Yoshimatsu et al. (2008a) obtained an LOD of $0.001 \mu \mathrm{g} \cdot \mathrm{m} \ell^{-1}$ in water samples using electrospun molecularlyimprinted nanoparticles with propranolol as a template. The $\mathrm{Ni}(\mathrm{II})-\mathrm{DMG}$ encapsulated-IIP nanofibre mats achieved very good recoveries (90-91\%) for the spiked CRM samples; in the previous study recoveries for the spiked CRM samples for the Ni(II)-DMG IIP were found to be $99-100 \%$ (Rammika et al., 2011). The values of LOD, LOQ and recoveries for the spiked CRM samples were better for Ni(II)-DMG IIP than for Ni(II)-DMG encapsulatedIIP nanofibre mats. This is testified to by the lower masses of the nanofibre mats used compared to the corresponding IIPs.

\section{Analysis of water samples}

The Ni(II)-DMG encapsulated-IIP nanofibre mats were then used to determine the concentration of $\mathrm{Ni}(\mathrm{II})$ in water samples (Table 5). The recoveries were very good and enrichment factors were found to range from 2 to 13 . This shows that the up to 13 -fold improvement in recoveries was achieved when using the Ni(II)-DMG encapsulated-IIP nanofibre mats. Enrichment factors of Ni(II)-DMG IIP were previously found to range from 2 to 18 (Rammika et al., 2011). Recoveries for the Ni(II)-DMG IIP were previously found to range from 93 to $100 \%$, while recoveries for the $\mathrm{Ni}(\mathrm{II})-\mathrm{DMG}$ nanofibre mats ranged from 83 to $89 \%$. Amais et al. (2007) used multi-wall carbon nanotubes as sorbent for on-line nickel preconcentration in water samples and obtained a recovery ranging from 95.7 to $99.1 \%$. The DMG non-imprinted nanofibre mats had recoveries ranging from 59 to $65 \%$ and the PSU had recoveries ranging from 55 to $62 \%$. Chronakris et al. (2006a) also achieved recoveries of $88 \%$ using PET as a supporting nanofibre matrix to encapsulate theophylline and $17 \beta$-estradiol imprinted nanoparticles. A recovery of $75 \%$ was achieved by Chronakris et al. (2006b) when they generated artificial molecular recognition sites in the nanofibre itself. Yoshimatsu et al. (2008a) achieved a recovery of $80 \%$

\begin{tabular}{|c|c|c|c|c|c|c|c|}
\hline \multicolumn{8}{|c|}{$\begin{array}{cc} & \text { Table } 3 \\
\text { Analytical quality control parameters determined using }\end{array}$} \\
\hline $\begin{array}{l}\text { Wavelength } \\
(\mathrm{nm})\end{array}$ & $\begin{array}{c}\text { Calibration } \\
\text { Linearity } \\
\mathbf{R}^{2}\end{array}$ & $\begin{array}{c}\text { Certified } \\
\text { concentration } \\
\left(\mu \mathrm{g} \cdot \mathrm{m} \ell^{-1}\right)\end{array}$ & $\begin{array}{c}\text { Concentration } \\
\text { found }(n=3) \\
\left(\mu g \cdot m \ell^{-1}\right)\end{array}$ & $\begin{array}{l}\text { Relative error } \\
(\%)\end{array}$ & $\begin{array}{c}\text { \%RSD } \\
(n=6)\end{array}$ & $\begin{array}{c}\text { LOD } \\
\left(\mu g \cdot m \ell^{-1}\right) \\
(n=5)\end{array}$ & $\begin{array}{c}\text { LOQ } \\
\left(\mu \mathrm{g} \cdot \mathrm{m} \ell^{-1}\right) \\
(\mathrm{n}=3)\end{array}$ \\
\hline 231.60 & 0.9954 & 0.900 & $\begin{array}{c}0.898 \\
(0.0013)\end{array}$ & +0.2222 & 4.57 & $\begin{array}{c}0.0004 \\
(0.0018)\end{array}$ & $\begin{array}{l}0.0012 \\
(0.002)\end{array}$ \\
\hline
\end{tabular}

*Standard deviations in brackets

\begin{tabular}{|c|c|c|c|c|}
\hline \multicolumn{5}{|c|}{$\begin{array}{c}\text { Table } 4 \\
\text { Analysis of SEP-3 CRM }\end{array}$} \\
\hline CRM & $\begin{array}{l}\text { Certified } \mathrm{Ni}(\mathrm{II}) \text { conc. } \\
\text { value }\left(\mu \mathrm{g} \cdot \mathrm{m} \ell^{-1}\right)\end{array}$ & \begin{tabular}{|}
$\mathrm{Ni}(\mathrm{II})$ conc. in sample \\
$\left(\mu \mathrm{g} \cdot \mathrm{m}^{-1}\right)(\mathrm{n}=3)$
\end{tabular} & $\begin{array}{c}\text { Amount of } \mathrm{Ni}(\mathrm{II}) \\
\text { added }\left(\mu \mathrm{g} \cdot \mathrm{m} \ell^{-1}\right)(\mathrm{n}=3)\end{array}$ & \% Recovery \\
\hline SEP-3 & 0.900 & 0.898 & $0,2,4$ & $-, 91,90$ \\
\hline
\end{tabular}




\begin{tabular}{|c|c|c|c|c|c|c|}
\hline \multicolumn{7}{|c|}{$\begin{array}{l}\text { Table } 5 \\
\text { Enrichment factors of } \mathrm{Ni}(\mathrm{II})-\mathrm{DMG} \text { nanofibre mats in aqueous samples }(n=3)\end{array}$} \\
\hline $\begin{array}{l}\text { Type of water } \\
\text { sample }\end{array}$ & $\begin{array}{l}\text { \%EE of PSU } \\
\text { nanofibre }\end{array}$ & $\begin{array}{c}\text { \%EE of DMG } \\
\text { non imprinted } \\
\text { nanofibre }\end{array}$ & $\begin{array}{l}\text { \%EE of } \mathrm{Ni}(\mathrm{II})- \\
\text { DMG imprinted } \\
\text { nanofibre }\end{array}$ & $\begin{array}{c}\text { aNi(II) conc. value got } \\
\text { without digestion } \\
\left(\mu \mathrm{g} \cdot \mathrm{m}^{-1}\right)\end{array}$ & $\begin{array}{c}\text { bNi(II) conc. value got } \\
\text { when using } \mathrm{Ni}(\mathrm{II})-\mathrm{DMG} \\
\text { nano fibre }\left(\mu \mathrm{g} \cdot \mathrm{m}^{-1}\right)\end{array}$ & $\mathrm{EF}^{*}$ \\
\hline Sea & 62 & 63 & 87 & 0.0015 & 0.0195 & 13 \\
\hline Town River & 55 & 59 & 89 & 0.0193 & 0.0583 & 3 \\
\hline Village River & 60 & 65 & 86 & 0.0112 & 0.0977 & 9 \\
\hline Treated sewage & 59 & 64 & 85 & 0.0181 & 0.1089 & 6 \\
\hline Untreated sewage & 61 & 64 & 83 & 0.0201 & 0.0467 & 2 \\
\hline
\end{tabular}

when they encapsulated propranolol-imprinted nanoparticles in poly(ethylene) terephthalate nanofibres. This shows that the binding sites in the nanofibre are available even after encapsulating.

\section{Conclusions}

The Ni(II)-DMG encapsulated-IIP nanofibre mats were prepared for the selective determination of $\mathrm{Ni}(\mathrm{II})$ relative to other closelyrelated metal ions in complex aqueous matrices. Though the time for rebinding was not reduced relative to Ni(II)-DMG IIP, the study was successful in that nanotechnology (electrospun nanofibres) was combined with imprinted polymers, opening a wider window for application of imprinted nanofibre mats for enriching metal ions in complex aqueous matrices. High $\mathrm{Ni}$ (II) recoveries with good \%RSD, EFs, LOQ and LOD were obtained with lesser masses of $\mathrm{Ni}(\mathrm{II})-\mathrm{DMG}$ encapsulated-IIP nanofibre mats relative to Ni(II)-DMG IIP. It was also found that the nanofibres were more recyclable than the IIPs. The performance of the $\mathrm{Ni}(\mathrm{II})-\mathrm{DMG}$ encapsulated-IIP nanofibre mats was validated by analysing a CRM, and then successfully using the mats to trap $\mathrm{Ni}(\mathrm{II})$ ions from sea, river and sewage water samples. From the results presented in this work, the Ni(II)-DMG encapsulated-IIP nanofibre mats offer a good opportunity to be used as sorbent in solid-phase extraction from aqueous samples. This is mainly based on their high surface-to-volume ratio which improves the accessibility to analytes of the imprinted cavities in polymers.

\section{Acknowledgements}

The authors wish to thank the 'Strengthening Capacity in Agricultural Research and Development in Africa (SCARDA)' programme for financial support and Department of Agricultural Research, (Botswana) for granting study leave to the first author.

\section{References}

AMAIS RS, RIBEIRO JS, SEGATELLI MG, YOSHIDA IVP, LUCCAS PO and TARLEY CRT (2007) Assessment of nanocomposite alumina supported on multi-wall carbon nanotubes as sorbent for on-line nickel preconcentration in water samples. Sep. Sci. Technol. 58 (1) 122-128.

BALCERZAK M (2002) Sample digestion methods for the determination of traces of precious metals by spectrometric techniques. Anal. Sci. 18 (7) 737-750.

BHASKARA SPVR and REDDY BR (2002) Liquid-liquid extraction of nickel at macro-level concentration from sulphate/chloride solutions using phosphoric acid based extractants. Miner. Eng. 15 (6) $461-464$

BURGER K, RUFF I and RUFF F (1965) Some theoretical and practical problems in the use of organic reagents in chemical analysis - IV: Infra-red and ultra-violet spectrophotometric study of the dimethylglyoxime complexes of transition metals. J. Inorg. Nucl. Chem. 27 (1) 179-190

CARDOSO WS, DIAS VLN, COSTA WM, RODRIGUES IA, MARQUES EP, SOUSA AG, BOAVENTURA J, BERERRA
CWB, SONG C, LIU H, ZHANG J and MARQUES ALB (2009) Nickel-dimethylglyoxime complex modified graphite and carbon paste electrodes: preparation and catalytic activity towards methanol/ethanol oxidation. J. Appl. Electrochem. 39 (1) 55-64.

CARTER SR and RIMMER S (2002) Molecular recognition of caffeine by shell molecular imprinted core-shell polymer particles in aqueous media. Adv. Mater. 14 (9) 667-670.

CARTER SR and RIMMER S (2004) Surface molecularly imprinted polymer core-shell particles. Adv. Funct. Mater. 14 (6) 553-561.

CHANG FC, LO SL and KO CH (2007) Recovery of copper and chelating agents from sludge extracting solutions. Sep. Purif. Technol. 53 (1) 49-56.

CHRONAKIS IS, JAKOB A, HAGSTROM B and YEI L (2006a) Encapsulation and selective recognition of molecularly imprinted Theophylline and 17ß-Estradiol nanoparticles within electrospun polymer nanofibres. Langmuir 22 (21) 8960-8965.

CHRONAKIS IS, MILOSEVIC B, FRENOT A and YE L (2006b) Generation of molecular recognition sites in electrospun polymer nanofibres via molecular imprinting. Macromolecules 39 (1) 357-361.

DE SOUSA CSD and KORN M (2001) Effects of ultrasonic irradiation on the spectrophotometric determination of nickel with dimethylglyoxime. Anal. Chim. Acta 444 (2) 309-315.

DHAKATE R and SINGH VS (2008) Heavy metal contamination in groundwater due to mining activities in Sukinda valley, Orissa A case study. J. Geog. Reg. Plan. 1 (4) 58-67.

DUAN HG, XIE EQ, ZHAO JG and JIA CW (2008) Preparation and characterisation of ultrafine and uniform $\mathrm{TiO}_{2}$ nanofibres. Mater. Sci. Technol. 24 (2) 241-244.

ERSHOVA NI and IVANOV VM (2000) Improvement of direct determination of trace nickel in environmental samples by diffuse reflection spectroscopy using chromaticity characteristics. J. Anal. Chem. 367 (2) 210-211.

FLAVIN K and RESMINI M (2009) Imprinted nanomaterials: a new class of synthetic receptors. Anal. Bioanal. Chem. 393 437-444.

GRIFFING M, DE VRIES T and MELLON MG (1947) Spectrographic examination of organic precipitates. Anal. Chem. 19 (9) 654-655.

GUAN G, LIU B, WANG Z and ZHANG Z (2008) Imprinting of molecular recognition sites on nanostructures and its applications in chemosensors. Sensors 8 (12) 8291-8320.

HENNION MC (1999) Solid-phase extraction: Method development, sorbents and coupling with liquid chromatography. J. Chromatogr. $A 856$ (1-2) 3-54.

HONG JJ, YANG SM, LEE CH, CHOI YK and KAJIUCHI T (1998) Ultrafiltration of divalent metal cations from aqueous solution using polycarboxylic acid type biosurfactant. J. Colloid Interface Sci. 202 (1) 63-73.

JANTARAT C, TANGTHONG N, SONGKRO S, MARTIN GP and SUEDEE R. (2008) S-propranolol imprinted polymer nanoparticleon-microsphere composite porous cellulose membrane for the enantionselectivity controlled delivery of racemic propranolol. Int J. Pharm. 349 (1-2) 212-225.

KI CD, OH C, OH SG and CHANG JY (2002) The use of a thermally reversible bond for molecular imprinting of silica spheres. $J$. Am. Chem. Soc. 124 (50) 14838-14839.

KRIEGEL C, ARRECHI A, KIT K, McCLEMENTS DJ and WEISS $\mathrm{J}$ (2008) Fabrication, functionalization, and application of electrospun biopolymer nanofibers. Crit. Rev. Food Sci. Nut. 48 (8) 775-797. 
KRISHNA PG, GLADIS JM, RAO TP and NAIDU GR (2004) Selective recognition of neodymium (III) using ion imprinted polymer particles. J. Mol. Recognit. 18 (1) 109-116.

KUMBASAR RA and SAHIN I (2008) Separation and concentration of cobalt from ammoniacal solutions containing cobalt and nickel by emulsion liquid membranes using 5,7-dibromo-8-hydroxyquinoline (DBHQ). J. Membr. Sci. 325 (2) 712-718.

LEHMANN M, BRUNNER H and TOVAR GEM (2002) Selective separations and hydrodynamic studies: A new approach using molecularly imprinted nanosphere composite membranes. Desalination 149 (1-3) 315-321.

LIMA EC, BARBOSA F, KRUG FJ, SILVA MM and VALE MGR (2000) Comparison of ultrasound-assisted extraction, slurry sampling and microwave-assisted digestion for cadmium, copper and lead determination in biological and sediment samples by electrothermal atomic absorption spectrometry. J. Anal. At. Spectrom. 15 (8) 995-1000

MANSOUR SA and SIDKY MM (2002) Ecotoxicological Studies. 3 . Heavy metals contaminating water and fish from Fayoum Governorate, Egypt. Food Chem. 78 (1) 15-22.

MASSOUMI A and HEDRICK CE (1969) Solvent extraction of metal ions and surface active agents from saturated sodium chloride brine. J. Chem. Eng. Data 14 (1) 52-54.

METHOD 3005A (1992) Acid digestion of waters for total recoverable or dissolved metals for analysis by FLAA or ICP spectroscopy, Rev. 1, EPA, Woodrow Wilson Plaza, USA, 1992.

MIAO J, MIYAUCHI M, SIMMONS TJ, DORDICK JS and LINHARDT RJ (2010) Electrospinning of nanomaterials and applications in electronic components and devices. J. Nanosci. Nanotechnol. 10 (9) 5507-5519.

MILLER JR, HUDSON-EDWARDS KA, LECHLER PJ, PRESTON D and MACKLIN MG (2004) Heavy metal contamination of water, soil and produce within riverine communities of the Río Pilcomayo basin, Bolivia. Sci. Total Environ. 320 (2-3) 189-209.

MOMODU MA and ANYAKORA CA (2010) Heavy metal contamination of ground water: The Surulere case study. Res. J. Environ. Earth Sci. 2 (1) 39-43.

MONTGOMERY DC (2005) Design and Analysis of Experiments $\left(6^{\text {th }}\right.$ edn.). John Wiley and Sons, New York.

NISHIDE H, DEGUCHI J and TSUCHIDA E (1976) Selective adsorption of metal ions on crosslinked poly(vinylpyridine) resin prepared with a metal ion as a template. Chem. Lett. 5 (2) 169-174.

NYQUIST RA (2001) Interpreting Infrared, Raman and Nuclear Magnetic Resonance Spectroscopy, Vol. 1. Academic Press, Florida.

OTERO NG, VALIÑO CT, ROMANÍ JO, VÁZQUEZ EP, PIÑEIRO AM and BARRERA PB (2009) On-line ionic imprinted polymer selective solid-phase extraction of nickel and lead from seawater and their determination by inductively coupled plasma-optical emission spectrometry. Anal. Bioanal. Chem. 395 (4) 1107-1115.

POURREZA N, ZOLGHARNEIN J, KIASAT AR and DASTYAR T (2010) Silica gel-polyethylene glycol as a new adsorbent for solid phase extraction of cobalt and nickel and determination by flame atomic absorption spectrometry. Talanta 81 (3) 773-777.

RAMAKRISHNA S, FUJIHARA K, TEO WE, LIM TC and MA Z (2005) An Introduction to Electrospinning and Nanofibres. World Scientific Publishing Co. Pty. Ltd, Singapore.

RAMAKRISHNAN K and RAO TP (2006) Ion imprinted polymer solid phase extraction (IIP-SPE) for preconcentrative separation of erbium(III) from adjacent lanthanides and yttrium. Sep. Sci. Technol. 41 (2) 233-246.

RAMMIKA M, DARKO G, SEWRY J, TSHENTU and TORTO N (2011) Dimethylglyoxime based ion-imprinted polymer for the determination of $\mathrm{Ni}(\mathrm{II})$ ions from aqueous samples. Water $S A 37$ (3) 321-330.

RAO MS and DAVE BC (1998) Selective intake and release of proteins by organically-modified silica sol-gels. J. Am. Chem. Soc. 120 13270-13271.

RECHCIGL JE and PAYNE GG (1989) Comparison of a microwave digestion system to other digestion methods for plant tissue analysis. Poster presented at at 1989 Annual Meetings of the American Society of Agronomy, Crop Science Society of America and Soil
Society of America, Las Vegas, Nevada, 1989.

RICO MA. C, HERNÁNDEZ LM and GONZÁLEZ MA. J (1989) Water contamination by heavy metals $(\mathrm{Hg}, \mathrm{Cd}, \mathrm{Pb}, \mathrm{Cu}$ and $\mathrm{Zn})$ in Doñana National Park (Spain). Bull. Environ. Contam. Toxicol. 42 (4) 582-588.

ROMANÍ JO, PI NEIRO AM, BARRERA PB and ESTEBAN AM (2009) Inductively coupled plasma-optical emission spectrometry/ mass spectrometry for the determination of $\mathrm{Cu}, \mathrm{Ni}, \mathrm{Pb}$ and $\mathrm{Zn}$ in seawater after ionic imprinted polymer based solid phase extraction. Talanta 79 (3) 723-729.

RUOTOLO LAM and GUBULIN JC (2002) Electrodeposition of copper ions on fixed bed electrodes: Kinetic and hydrodynamic study. Braz. J. Chem. Eng. 19 (1) 105-118.

SARIN RK, SRIVASTAVA S, SRIVASTAVA AK, ANIL G and REDDY MRP (2004) Multielement determination in gum opium by microwave digestion and inductively coupled plasma optical emission spectroscopy. Chem. Pap. 58 (2) 101-103.

SHAO X, HU S and GOVIND R (1991) Continuous membrane dialysis using ion-exchange resin suspension for extracting metal ions. Ind. Eng. Chem. Res. 30 (6) 1231-1239.

SOCRATES G (2001) Infrared and Raman Characteristic Group Frequencies: Tables and Charts (3rd edn.). John Wiley and Sons, Chichester.

SUBBIAH T, BHAT GS, TOCK RW, PARARNESWARAN S and RAMKUMAR SS (2005) Electrospinning of nanofibers. J. Appl. Polym. Sci. 96 (2) 557-569.

TEO WE and RAMAKRISHNA S (2009) Electrospun nanofibres as a platform for multifunctional, hierarchically organised nanocomposite. Compos. Sci. Technol. 69 (11-12) 1804-1817.

WANG HS, FU GD and LI XS (2009) Functional polymeric nanofibers from electrospinning. Recent Pat. Nanotechnol. 3 (1) 21-31.

WILSON K, YANG H, SEO CW and MARSHALL WE (2006) Select metal adsorption by activated carbon made from peanut shells. Bioresour. Technol. 97 (18) 2266-2270.

XIE CG, ZHANG ZP, WANG DP, GUAN GJ, GAO DM and LIU JH (2006) Surface molecular self-assembly strategy for TNT imprinting of polymer nanowire/nanotube arrays. Anal. Chem. 78 (24) 8339-8346.

XIE C, LIU B, WANG Z, GAO D, GUAN G and ZHANG Z (2008) Molecular imprinting at walls of silica nanotubes for TNT recognition. Anal. Chem. 80 (2) 437-443.

YANG HH, ZHANG SQ, TAN F, ZHUANG ZX and WANG XR (2005) Surface molecularly imprinted nanowires for biorecognition. J. Am. Chem. Soc. 127 (5) 1378-1379.

YANG J and BLACK J (1994) Competitive binding of chromium, cobalt and nickel to serum proteins. Biomater. 15 (4) 262-268.

YOSHIMATSU K, YE L, LINDBERG J and CHRONAKIS I (2008a) Selective molecular adsorption using electrospun nanofiber affinity membranes. Biosens. Bioelectron. 23 (7) 1208-1215.

YOSHIMATSU K, YE L, STENLUND P and CHRONAKIS I (2008b) A simple method for preparation of molecularly imprinted nanofiber materials with signal transduction ability. Chem. Commun. 17 2022-2024.

YOSHIMATSU K, REIMHULT K, KROZER A, MOSBACH K, SODE K and YE L (2007) Uniform molecurlarly imprinted microspheres and nanoparticles prepared by precipitation polymerisation: The control of particle size suitable for different analytical applications. Anal. Chim. Acta 584 (1) 112-121.

ZEN JM and LEE ML (1993) Determination of traces of nickel(II) at a perfluorinated ionomer/dimethylglyoxime mercury film electrode. Anal. Chem. 65 (22) 3238-3243.

ZHANG Y LIM CT, RAMAKRISHNA S and HUANG ZM (2005) Recent development of polymer nanofibers for biomedical and biotechnological applications. J. Mater. Sci.: Mater. Med. 16 (10) 933-946.

ZHU QH, HE JF and FENG JY (2007) Optimization of the process parameters of synthesis of vinblastine imprinted polymer. Eur. Polym. J. 43 (9) 4043-4051.

ZHU X, CUI Y, ZOU X and LI Z (2009) Selective solid-phase extraction of lead(II) from biological and natural water samples using surface-grafted lead(II)-imprinted polymers. Microchim. Acta 164 (1-2) $125-132$ 